\title{
Anti-Cancer Effect of Cap-Translation Inhibitor 4EGI-1 in Human Glioma U87 Cells: Involvement of Mitochondrial Dysfunction and ER Stress
}

\author{
Ming Wua Chi Zhang ${ }^{a}$ Xue-Jun Lia Qing Liu ${ }^{a}$ Siyi Wanggou ${ }^{a}$ \\ aDepartment of Neurosurgery, Xiangya Hospital, Central-South University, Changsha, Hunan, PR China
}

\section{Key Words}

4EGI-1 • Glioma $・$ U87 cells $・$ Mitochondrial dysfunction $・$ ER stress

\begin{abstract}
Background: Cancer cells are frequently addicted to deregulated oncogenic protein translation that usually arises as a consequence of increased signaling flux from eIF4F activation. The small molecule 4EG-I, a potent inhibitor of translation initiation through disrupting eIF4E/ eIF4G interaction, has been shown to exert anticancer effects in animal models of human cancers. Methods: Here, we extensively investigated the anticancer activity of 4EGI-1 in human glioma U87 cells. The anti-cancer effects of 4EGI-1 were measured by cell viability, lactate dehydrogenase (LDH) release, TUNEL staining, flow cytometry and western blot analysis in vitro, and also examined in a U87 xenograft model in vivo. The potential underlying molecular mechanisms were investigated by measuring mitochondrial function and ER stress. Results: We found that 4EGI-1 impaired the assembly of the eIF4F complex and decreased the expression of the eIF4E regulated proteins. The results of TUNEL staining and flow cytometry showed that 4EGI-1 treatment induced apoptotic cell death in a dose-dependent manner. Furthermore, 4EGI-1-induced apoptosis in U87 cells was associated with mitochondrial dysfunction and activation of the intrinsic mitochondrial pathway, which was dependent on the induction of the pro-apoptotic protein Bax. In addition, 4EGI-1 treatment triggered ER stress, which was evidenced by morphological changes of ER lumen and ER calcium release, as well as the dosedependent increases in the expression of ER stress related proteins. Moreover, knockdown of the ER chaperone GRP-78 through siRNA was shown to partially reverse the 4EGI-1-induced ER stress in U87 cells. In vivo, 4EGI-1 strongly inhibited growth of U87 glioma xenografts without any apparent organ related toxicities. Conclusion: These data indicate that the use of inhibitors that directly target the translation initiation complex eIF4F could represent a potential novel approach for human glioma therapy.
\end{abstract}




\section{Introduction}

Gliomas are the most common type of primary brain tumors, and account for $80 \%$ of primary central nervous system (CNS) tumors diagnosed between 2005 and 2009 in the United States [1]. The current classification system stratifies gliomas into four grades (IIV) based on several histological criteria, and the most common and aggressive subtype is glioblastoma (GBM), the grade IV astrocytoma [2]. The 5-year survival rate after GBM diagnosis is only $4.7 \%$, as compared with an average 5-year survival rate in breast cancer of $89 \%$ and prostate of nearly 100\% [3-6]. Despite advances in standard therapy, including the addition of temozolomide (TMZ), which increased median survival of GBM patients by a mere 2 months, the prognosis for patients with GBM remains poor [3, 7].

Eukaryotic translation initiation, the process leading to the positioning of the $80 \mathrm{~S}$ ribosome at the start codon of an mRNA, requires a group of proteins known as eukaryotic initiation factors (eIFs) [8]. Deregulated translation initiation is implicated extensively in cancer initiation and progression, and usually arises as a consequence of increased signaling flux from eIF4F activation $[9,10]$. Enhanced assembly of the eIF4F translation initiation complex drives cap-dependent translation, and affected the expression of a pool of mRNAs, which encodes several angiogenesis factors, onco-proteins, pro-survival proteins, and proteins involved in cancer invasion and metastasis [11]. The assembly of eIF4F complex is largely dependent on the availability of eIF4E, which is bound to the eIF4E binding proteins (4EBPs) under normal conditions. The 4EBP1 protein prevents the assembly of eIF4F by competing with eIF4G to bind to eIF4E. Previous studies showed that aberrant expression of eIF4E results in malignant transformation and increased cancer susceptibility $[12,13]$. Treatment with eIF4E anti-sense RNA inhibited translation initiation and growth of cancer cells, and also inhibited tumor growth in animal models [14]. A small molecular compound termed 4EGI-1 was found to mimic 4EBP function and thereby disrupts eIF4EeIF4G interaction [15]. It was previously demonstrated that 4EGI-1 reduces expression of apoptotic regulators, such as Bcl-xL and c-Myc, and inhibits cell proliferation in many cancer cell lines $[15,16]$. However, the role of 4EGI-1 in human glioma cells and the potential mechanisms underlying its anti-cancer activity have not been elucidated.

In the present study, we investigated the in vitro activity of the cap-dependent translation inhibitor 4EGI-1 and its potential anti-cancer activity in human glioma U87 cells, and we showed that 4EGI-1 effectively kills U87 cells through inducing apoptotic cell death. 4EGI-1 induced mitochondrial dysfunction and activation of intrinsic apoptotic pathway, which was mediated by up-regulation of pro-apoptotic protein Bax, and also induced ER stress through activation of GRP-78 in U87 cells. We suggest that targeting eIF4F translation initiation complex might be an ideal strategy for anti-cancer drug research for glioma patients.

\section{Materials and Methods}

\section{Reagents and cell culture}

The 4EGI-1 was purchased from Chembridge (San Diego, USA). The pan-caspase inhibitor Z-VADfmk, caspase-9 inhibitor Z-LEHD-fmk and thapsigargin (Tg) were obtained from Promega (Madison, WI). Human glioma U87 cells were obtained from the American Type Culture Collection (Rockville, MD, USA) and cultured in Dulbecco's modified Eagle's medium (DMEM), containing 10\% fetal bovine serum (FBS), $100 \mathrm{U}$ penicillin and $100 \mathrm{U}$ streptomycin at $37^{\circ} \mathrm{C}$ in a humidified incubator of $5 \% \mathrm{CO}_{2}$ and $95 \%$ air.

\section{7-Methyl-guanosine ( $\mathrm{m}^{7}$-GTP) cap affinity assay}

The $\mathrm{m}^{7}$-GTP assay was performed as previously described [17]. Briefly, U87 cells were washed three times with phosphate buffered saline (PBS) and lysed in lysis buffer containing 1\% digitonin. Cell lysates were clarified by centrifugation at $11000 \mathrm{~g}$ and $4^{\circ} \mathrm{C}$ for $30 \mathrm{~min}$, and supernatants were incubated with $7 \mathrm{~m}$-GTP Sepharose beads (Invitrogen, CA, USA) at $4^{\circ} \mathrm{C}$ for $2 \mathrm{~h}$ with constant shaking. Beads were washed three times with PBS and denatured, and the supernatants were separated by SDS-PAGE for western blot analysis.

\section{KARGER}




\section{Cellular Physiology Cell Physiol Biochem 2016;40:1013-1028

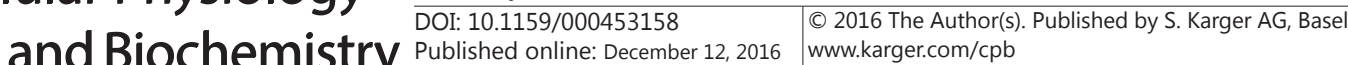 \\ Wu et al.: Anti-Cancer Effect of 4EGI-1 in Glioma Cells}

Cell viability assay

Cellviabilityassaywasperformedbyusinga3-(4,5-dimethylthiazol-2-yl)-5-(3-carboxymethoxyphenyl)2-(4-sulfophenyl)-2H-tetrazolium salt (MTS) that can be reduced to purple-coloured formazan by intact cells. After various treatments, cell viability was assessed using the Cell Titer 96 Aqueous One Solution Cell Proliferation Assay Kit (Promega, Madison, WI) according to the manufacturer's instructions. The absorbance was measured with an automatic microplate reader at a wavelength of $492 \mathrm{~nm}$. Results are presented as a percentage of the control.

Lactate dehydrogenase (LDH) assay

Cytotoxicity was determined by the release of LDH with a diagnostic kit (Jiancheng Bioengineering, Nanjing, China) according to the manufacturer's instructions. Briefly, $50 \mu \mathrm{l}$ of supernatant from each well was collected to assay LDH release. The samples were incubated with NADH and pyruvate for $15 \mathrm{~min}$ at $37^{\circ} \mathrm{C}$, and the reaction was stopped by adding $0.4 \mathrm{M} \mathrm{NaOH}$. The activity of LDH was calculated from the absorbance at $440 \mathrm{~nm}$, and background absorbance from culture medium that was not used for any cell cultures was subtracted from all absorbance measurements.

TUNEL staining

TUNEL staining was performed to detect apoptotic cell death using an in situ cell death detection kit. Briefly, U87 cells were fixed by immersing slides in freshly prepared $4 \%$ methanol-free formaldehyde solution in PBS for $20 \mathrm{~min}$ at room temperature. The cells were then permeabilized with $0.2 \%$ Triton X-100 for $5 \mathrm{~min}$. Cells were labeled with fluorescein TUNEL reagent mixture for $60 \mathrm{~min}$ at $37^{\circ} \mathrm{C}$ according to the manufacturer's suggested protocol (Promega, Madison, WI, USA). Subsequently, the slides were examined by fluorescence microscopy and the number of TUNEL-positive (apoptotic) cells was counted. DAPI (10 $\mu \mathrm{g} /$ $\mathrm{ml}$ ) was used to stain the nucleus.

\section{Flow cytometry}

U87 cells were harvested $24 \mathrm{~h}$ after 4 EGI- 1 treatment, washed with ice-cold $\mathrm{Ca}^{2+}$ free PBS, and resuspended in binding buffer. Cell suspension was transferred into a tube and double-stained for $15 \mathrm{~min}$ with the Alexa Fluor 488-conjugated annexin V (AV) and propidium iodide (PI) at room temperature in the dark. After addition of $400 \mu$ l binding buffer, the stained cells were analyzed by an FC500 flow cytometer with the fluorescence emission at $530 \mathrm{~nm}$ and $>575 \mathrm{~nm}$. The CXP cell quest software (Beckman-Coulter, USA) was used to count the number of $\mathrm{AV}^{+} / \mathrm{PI}$ and $\mathrm{AV}^{+} / \mathrm{PI}^{+}$cells, and analyzed the results.

\section{Colony Formation Assay}

Cell proliferation was assessed by colony formation assay. Briefly, one thousand cells were seeded onto 60-mm dishes and incubated overnight. Cells were treated with 4EGI- 1 at different concentrations for 72 $\mathrm{h}$ and then fixed with methanol and stained with $0.25 \%$ crystal violet. Colonies containing $>30$ cells were counted under a dissecting microscope. The results are reported as a percentage of the colonies in untreated cultures of each corresponding clone.

\section{Measurement of mitochondrial membrane potential (MMP)}

MMP was measured using the fluorescent dye rhodamine 123 (Rh123) as reported previously [18]. MMP depolarization resulted in the loss of Rh123 from the mitochondria and a decrease in intracellular fluorescence. Rh123 was added to cultured neurons to achieve a final concentration of $10 \mu \mathrm{M}$ for $30 \mathrm{~min}$ at $37^{\circ} \mathrm{C}$ after the cells had been treated and washed with PBS. The fluorescence was observed by using an Olympus BX60 microscope with the appropriate fluorescence filters (excitation wavelength of $480 \mathrm{~nm}$ and emission wavelength of $530 \mathrm{~nm}$ ).

\section{Measurement of mitochondrial ATP synthesis}

Isolated mitochondria were utilized to measure ATP synthesis up to $24 \mathrm{~h}$ after $4 \mathrm{EGI}-1$ treatment with a luciferase/ luciferin-based system as described elsewhere [19]. Thirty $\mu \mathrm{g}$ of mitochondria- enriched pellets were resuspended in $100 \mu \mathrm{l}$ of buffer A $(150 \mathrm{mM} \mathrm{KCl}, 25 \mathrm{mM}$ Tris- $\mathrm{HCl}, 2 \mathrm{mM}$ potassium phosphate, $0.1 \mathrm{mM}$ $\mathrm{MgCl}_{2}, \mathrm{pH} 7.4$ ) with $0.1 \% \mathrm{BSA}, 1 \mathrm{mM}$ malate, $1 \mathrm{mM}$ glutamate and buffer B (containing $0.8 \mathrm{mM}$ luciferin and $20 \mathrm{mg} / \mathrm{ml}$ luciferase in $0.5 \mathrm{M}$ Tris-acetate $\mathrm{pH}$ 7.75). The reaction was initiated by addition of $0.1 \mathrm{mM}$ ADP and monitored for 5 min using a microplate reader. 


\section{Cellular Physiology Cell Physiol Biochem 2016;40:1013-1028 \begin{tabular}{l|l|l} 
DOI: 10.1159/000453158 & $\begin{array}{l}\text { (c) } 2016 \text { The Author(s). Published by S. Karger AG, Basel } \\
\text { www.karger.com/cpb }\end{array}$
\end{tabular} \\ Wu et al:: Anti-Cancer Effect of 4EGI-1 in Glioma Cells}

Measurement of cytochrome c release

Cytochrome c release into the cytoplasm was assessed after subcellular fraction preparation. U87 cells were washed with ice-cold PBS for three times and lysed with a lysis buffer containing protease inhibitors. The cell lysate was centrifuged for $10 \mathrm{~min}$ at $750 \mathrm{~g}$ at $4^{\circ} \mathrm{C}$, and the pellets containing the nuclei and unbroken cells were discarded. The supernatant was then centrifuged at $15000 \mathrm{~g}$ for $15 \mathrm{~min}$. The resulting supernatant was removed and used as the cytosolic fraction. The pellet fraction containing mitochondria was further incubated with PBS containing $0.5 \%$ Trition X-100 for $10 \mathrm{~min}$ at $4^{\circ} \mathrm{C}$. After centrifugation at $16000 \mathrm{~g}$ for 10 $\mathrm{min}$, the supernatant was collected as mitochondrial fraction. The levels of cytochrome $\mathrm{c}$ in cytosolic and mitochondrial fractions were measured using the Quantikine M Cytochrome C Immunoassay kit obtained from the R\&D Systems (Minneapolis, MN, USA). Data were expressed as ng/mg protein.

Measurement of mitochondrial swelling

Mitochondria swelling was measured following a previously published protocol [20]. Briefly, isolated mitochondria were suspended in fresh swelling buffer (0.2 M sucrose, $10 \mathrm{mM}$ Tris-MOPS, pH 7.4, $5 \mathrm{mM}$ succinate, $1 \mathrm{mM}$ phosphate, $2 \mu \mathrm{M}$ rotenone, and $1 \mu \mathrm{M}$ EGTA-Tris, pH 7.4) at $0.5 \mathrm{mg} / \mathrm{ml}$, and the swelling of mitochondria was monitored by a decrease in absorbance at $540 \mathrm{~nm}$ in the presence of $\mathrm{CaCl}_{2}(200 \mu \mathrm{M})$.

Measurement of mitochondrial Ca ${ }^{2+}$ buffering capacity

Mitochondrial calcium buffering capacity was estimated with the $\mathrm{Ca}^{2+}$ sensitive Calcium Green $5 \mathrm{~N}$ fluorescent dye. Incubation medium was composed of $125 \mathrm{mM} \mathrm{KCl}, 20 \mathrm{mM}$ HEPES (pH 7.2), $2 \mathrm{mM} \mathrm{KH}_{2} \mathrm{PO}_{4}$, $2 \mathrm{mM} \mathrm{MgCl}{ }_{2}, 5 \mathrm{mM}$ succinate, $1 \mu \mathrm{M}$ rotenone and $0.2 \mathrm{mM}$ ADP, with $1 \mu \mathrm{g} / \mathrm{mL}$ oligomycin and $1 \mu \mathrm{M}$ Calcium Green 5N. Bolus additions of $\mathrm{CaCl}_{2}$ were made to the $60 \mu \mathrm{g}$ of mitochondria in suspension in $30 \mathrm{nM}$ increments and changes in Calcium Green $5 \mathrm{~N}$ fluorescence were recorded at an emission of $532 \mathrm{~nm}$.

\section{Electrophysiology and $\mathrm{Ca}^{2+}$ imaging}

Whole-cell recordings were performed following standard procedures using an EPC9 patch clamp amplifier as described previously [21]. Imaging of transient $\mathrm{Ca}^{2+}$ changes in U87 cells was started 25-30 min after establishing the whole-cell configuration. A multipoint confocal microscope using dual spinning disc technology, attached to an upright microscope and equipped with a 403 objective was used to acquire fluorescence images in parallel to the patch clamp recordings.

\section{Immunocytochemistry (ICC)}

After being fixed with $4 \%$ paraformaldehyde for $15 \mathrm{~min}$ at room temperature, U87 cells were washed with $\mathrm{NaCl} / \mathrm{Pi}$, permeabilized with $0.2 \%$ Triton X-100, and incubated with GRP-78 primary antibody overnight at $4^{\circ} \mathrm{C}$. Cells were then incubated with Alexa 488-conjugated secondary antibody for $2 \mathrm{~h}$ at $37^{\circ} \mathrm{C}$, and DAPI $(10 \mu \mathrm{g} / \mathrm{ml})$ was used to stain nucleus. Images were captured with an Olympus FV10i Confocal Microscope (Olympus, Tokyo, Japan). All images of one experiment were acquired with the same exposure time to allow comparisons of relative levels of immunoreactivity between the different treatment conditions. At least six images of each group were taken by an evaluator blinded to the experimental conditions.

\section{Western blotting}

Equivalent amounts of protein ( $60 \mu \mathrm{g}$ per lane) were loaded and separated by 10\% SDS-PAGE gels, and transferred to polyvinylidene difluoride (PVDF) membranes. Membranes were blocked with 5\% nonfat milk solution in tris-buffered saline with $0.1 \%$ Triton X-100 (TBST) for $1 \mathrm{~h}$, and then incubated overnight at $4^{\circ} \mathrm{C}$ with the primary p-4E-BP1, 4E-BP1, p-eIF4E, eIF4E, eIF4G, cyclin D1, cyclin D2, c-myc, survivin, totalcaspase-3, cleaved caspase-3, total-caspase-9, cleaved caspase-9, Bax, Bak, Bcl-2, p-PERK, PERK, XBP1, CHOP or $\beta$-actin antibody dilutions in TBST. After that the membranes were washed and incubated with secondary antibody for $1 \mathrm{~h}$ at room temperature. Immunoreactivity was detected with Super Signal West Pico Chemiluminescent Substrate (Thermo Scientific, Rockford, IL, USA). An analysis software named Image J (Scion Corporation) was used to quantify the optical density of each band.

Hematoxylin and eosin (H\&E) staining

Isolated organ tissues were fixed in formalin and embedded in paraffin. Five micrometer sections were cut and stained with H\&E. All sections were evaluated by an independent observer, who was blinded to the grouping and experimental protocols. 
Mouse model of tumor xenograft growth

The U87 xenograft glioma model was established to confirm the anti-tumor effect of 4EGI-1 in vivo. Briefly, athymic nude mice (4-5 weeks, $n=18$ ) were anesthetized with ethylcarbamate and injected s.c. with $5 \times 10^{5}$ U87 cells into the right flanks. As shown in Fig. 7B, mice were randomly divided into control group (treated i.p. with $1.5 \mu \mathrm{l}$ DMSO) and 4EGI-1 group (treated i.p. with $75 \mathrm{mg} / \mathrm{kg} 4 \mathrm{EGI}-1$ in $1.5 \mu \mathrm{l}$ DMSO). Animals in 4EGI-1 group were treated with $75 \mathrm{mg} / \mathrm{kg}$ 4EGI-1 by intraperitoneal administration every day from day zero for U-87 cell implantation. Tumor volume was measured every four days from day 4 and calculated by the following formula: $0.4 \mathrm{x}$ length $\mathrm{x}$ width ${ }^{2}$. Body weights and tumor volumes were measured at day 28. All experimental protocols and animal handling procedures were performed in accordance with the National Institutes of Health (NIH) guidelines for the use of experimental animals and approved by the Institutional Animal Care and Use Committee of the Fourth Military Medical University.

\section{Statistical analysis}

Statistical analysis was performed using SPSS 16.0, a statistical software package. Statistical evaluation of the data was performed by one-way analysis of variance (ANOVA) followed by Bonferroni's multiple comparisons or unpaired $t$ test (two groups). A value of $p<0.05$ was considered statistically significant.

\section{Results}

4EGI-1 impairs the formation of eIF4F complex in U87 cells

Because 4EGI-1 mimics 4E-BP function by competing for eIF4E and eIF4G interaction, we first examined the expression of 4E-BP1 and eIF4E proteins and their phosphorylation

A

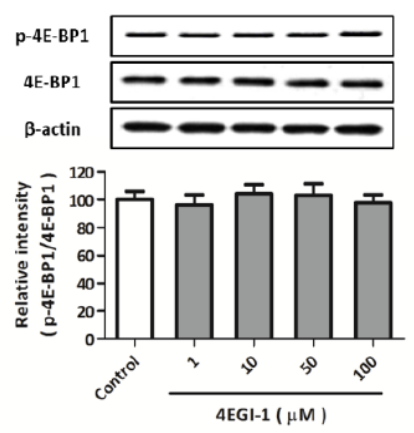

B

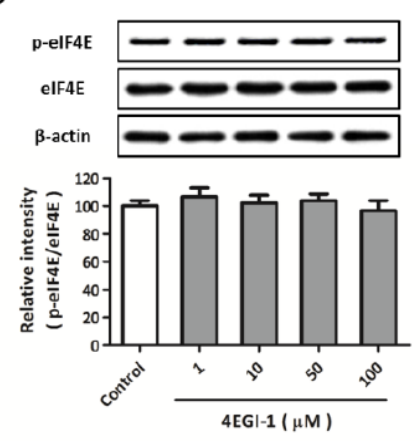

C

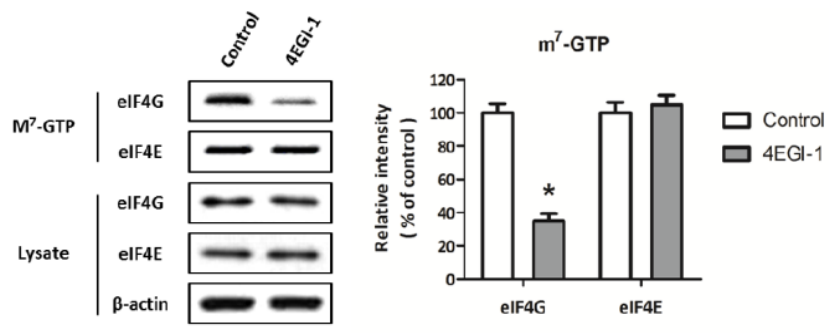

D
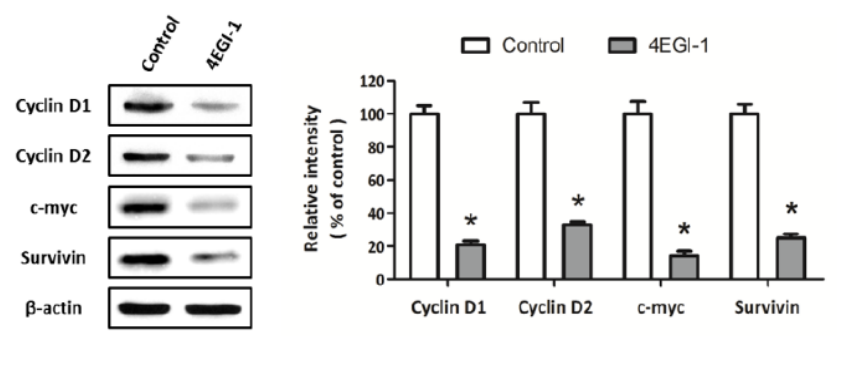

Fig. 1. 4-EGI-1 disrupted eIF4F complex formation of and inhibited cap-dependent protein expression. U87 cells were treated with 4EGI-1 at different concentrations for $6 \mathrm{~h}$, and the expression of p-4E-BP1, 4E-BP1 (A), p-eIF4E and eIF4E (B) were detected by western blot analysis. U87 cells were treated with $50 \mu \mathrm{M} 4 \mathrm{EGI-}$ 1 for $6 \mathrm{~h}$, and $\mathrm{m}^{7}$ GTP pull-down assays were performed to assay eIF4E and eIF4G interaction (C). U87 cells were treated with $50 \mu \mathrm{M} 4 \mathrm{EGI}-1$ for $6 \mathrm{~h}$, and western blot analysis was used to detecte the expression of cyclin D, c-myc and survivin (D). Data are shown as mean \pm SEM of five experiments. ${ }^{*} p<0.05$ vs. Control.

\section{KARGER}




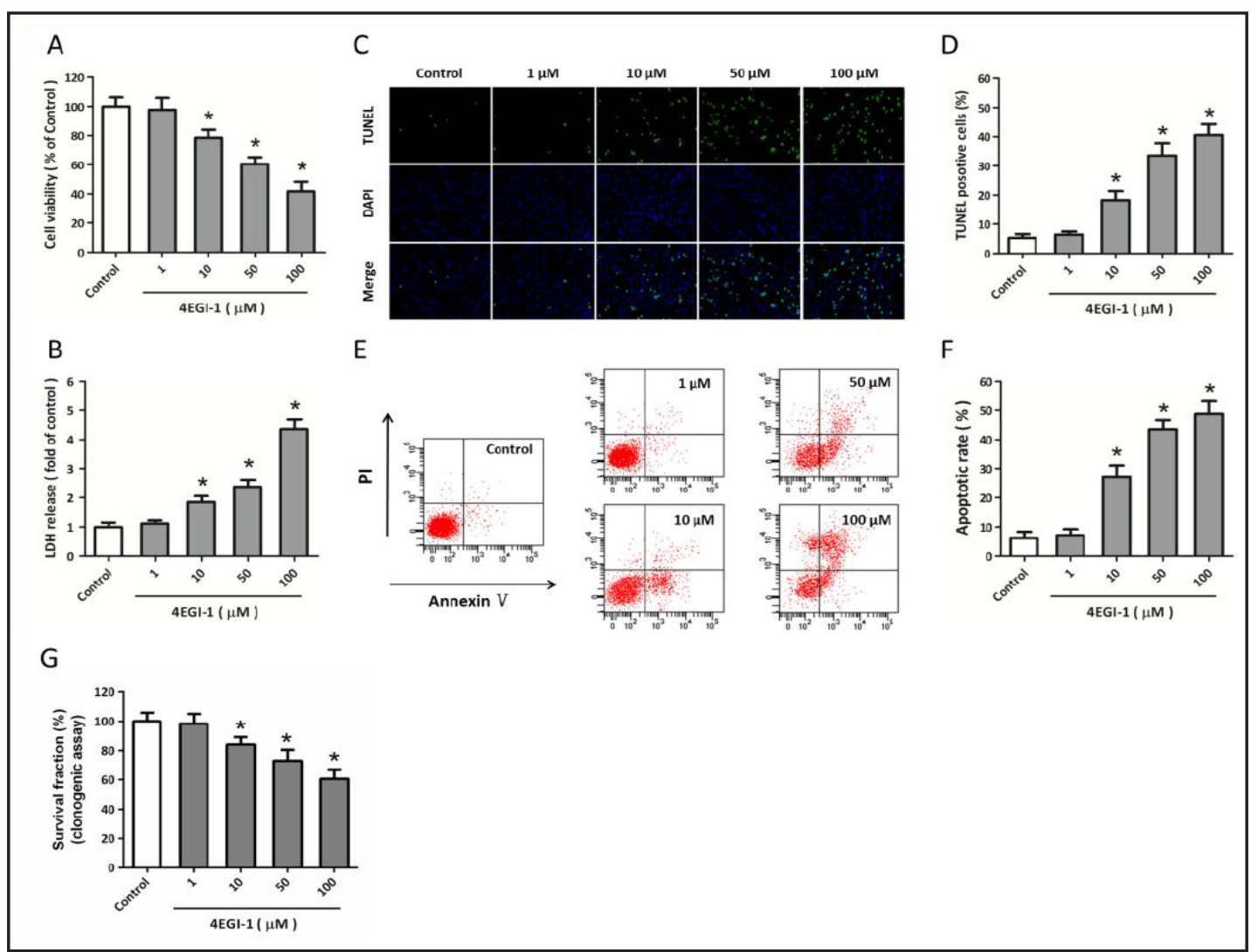

Fig. 2. 4EGI-1 inhibits cell proliferation via inducing apoptosis in U87 cells. U87 cells were treated with 4EGI-1 at different concentrations, cell viability (A), LDH release (B), TUNEL staining (C and D), and flow cytometry ( $\mathrm{E}$ and $\mathrm{F}$ ) were measured at $24 \mathrm{~h}$ later. The cell proliferation was measured by colony formation assay at $72 \mathrm{~h}(\mathrm{G})$. Data are shown as mean \pm SEM of five experiments. ${ }^{*} p<0.05$ vs. Control.

levels after 4EGI-1 treatment in U87 cells. The results of western blot showed that 4EGI-1 at all concentrations used did not alter the expression of 4E-BP1 and p-4E-BP1 (Fig. 1A). A similar result in expression and phosphorylation of eIF4E was also observed (Fig. 4B). We then examined whether 4EGI-1 inhibited the interaction between eIF4E and eIF4G by pull-down assays using $7 \mathrm{~m}$-GTP sepharose beads that mimic the cap structure of mRNAs. As shown in Fig. 1C, treatment with 4EGI-1 strongly decreased the amount of eIF4G bound to eIF4E in U87 cells. In addition, we also investigated the effects of 4EGI-1 on the expression of c-myc, survivin and cyclin D proteins (Fig. 1D). The significant down-regulation of c-myc, survivin, cyclin D1 and cyclin D2 was observed after 4EGI-1 treatment, indicating 4EGI-1 attenuated the expression of cell cycle and survival proteins regulated by a cap-dependent translation mechanism.

\section{EGI-1 inhibits cell proliferation via inducing apoptosis in U87 cells}

To investigate the effects of 4EGI-1 on glioma cells proliferation and survival, U87 cells were treated with 4 EGI-1 at various concentrations for $24 \mathrm{~h}$. The results showed that 4EGI-1 significantly decreased cell viability (Fig. 2A) but increased LDH release in a dosedependent manner in U87 cells. To determine whether 4EGI-1 induced anti-cancer effects in U87 cells was mediated by pro-apoptotic activity, TUNEL staining was performed to detected apoptotic cell death (Fig. 2C). There was no obvious TUNEL positive cells in control group, whereas E4GI-1 incubation increased the number of TUNEL positive cells in a dosedependent fashion (Fig. 2D). Flow cytometry was used to further confirm the pro-apoptotic effect of 4EGI-1 in U87 cells (Fig. 2E), and the results showed that 4EGI-1 treatment led 


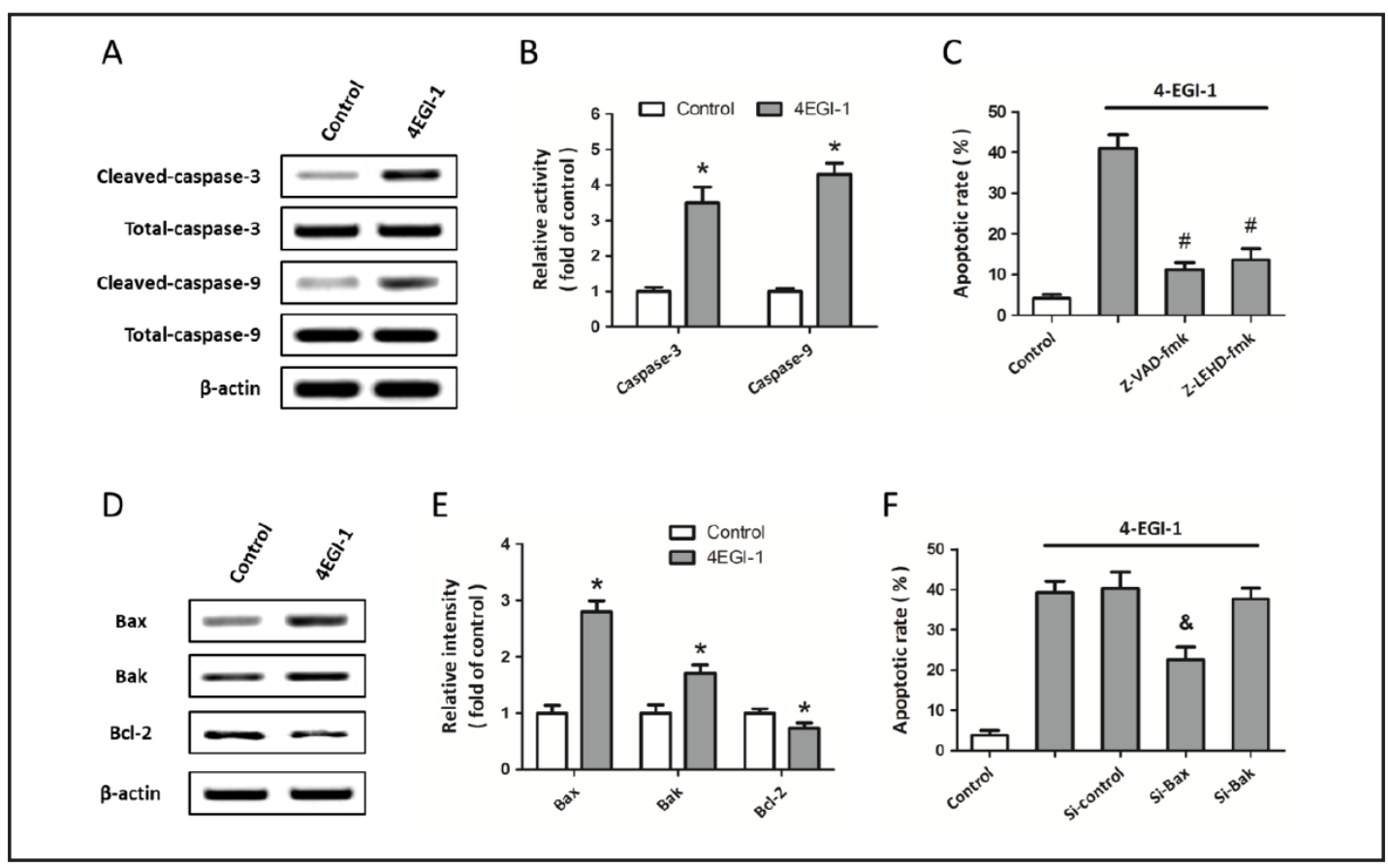

Fig. 3. 4EGI-1 induces intrinsic apoptosis through Bax activation. U87 cells were treated with $50 \mu \mathrm{M} 4 \mathrm{EGI}-1$ for $24 \mathrm{~h}$, and activation of caspase- 3 and caspase- 9 were detected by western blot analysis (A) and calculated (B). U87 cells were treated with $50 \mu \mathrm{M} 4 \mathrm{EGI}-1$ in the presence or absence of caspase inhibitor Z-VAD-fmk or caspase-9 inhibitor Z-LEHD-fmk for $24 \mathrm{~h}$, and apoptotic rate was measured by flow cytometry (C). U87 cells were treated with $50 \mu \mathrm{M} 4 \mathrm{EGI}-1$ for $24 \mathrm{~h}$, and the expression of Bax, Bak and Bcl-2 were detected by western blot analysis (D) and calculated (E). U87 cells were transfected with Bax specific siRNA (Si-Bax), Bak specific siRNA (Si-Bak) or control siRNA (Si-control) for $48 \mathrm{~h}$ before 4EGI-1 exposure, and apoptotic rate was measured by flow cytometry (F). Data are shown as mean \pm SEM of five experiments. ${ }^{*} p<0.05$ vs. Control. ${ }^{*} p<0.05$ vs. 4 EGI-1. ${ }^{\&} p<0.05$ vs. Si-control.

to a dose-dependent increase in apoptotic rate in U87 cells (Fig. 2F). In addition, we also measured the cell proliferation using colony formation assay, and the results showed that 4EGI-1 at 10, 50 and $100 \mu \mathrm{M}$ were effective to reduce cell proliferation of U87 cells at $72 \mathrm{~h}$ after treatment (Fig. 2G).

\section{EGI-1 induces intrinsic apoptosis through Bax activation}

To determine whether the intrinsic mitochondrial pathway mediates apoptosis induced by 4EGI-1 in our in vitro model, we next determined the activation of caspase-9, and its downstream effector caspase-3 using western blot (Fig. 3A). The results showed that the cleavage of caspase- 3 and caspase- 9 was significantly increased in 4EGI-1 treated U87 cells (Fig. 3B). The pan-caspase inhibitor Z-VAD-fmk and caspase-9 inhibitor Z-LEHD-fmk were used to further confirm the involvement of these two caspase family proteins. As presented in Fig. 3C, both these two caspase inhibitors were able to reduce the 4EGI-1 induced apoptosis in U87 cells (68\% and $75 \%$ reduction, respectively), indicating the involvement of the intrinsic apoptotic pathway. We also detected the effects of 4EGI-1 on the expression of Bcl-2 family proteins (Fig. 3D). A significant increase in Bax and Bak, as well as decrease in Bcl2 expression was observed after 4EGI-1 treatment (Fig. 3E). Furthermore, the silencing of Bax but not Bak using specific targeted siRNA partially prevented 4EGI-1 induced apoptosis, suggesting that 4EGI-1 induced anti-cancer effects could be associated with Bax-dependent intrinsic apoptotic cascades.

\section{KARGER}




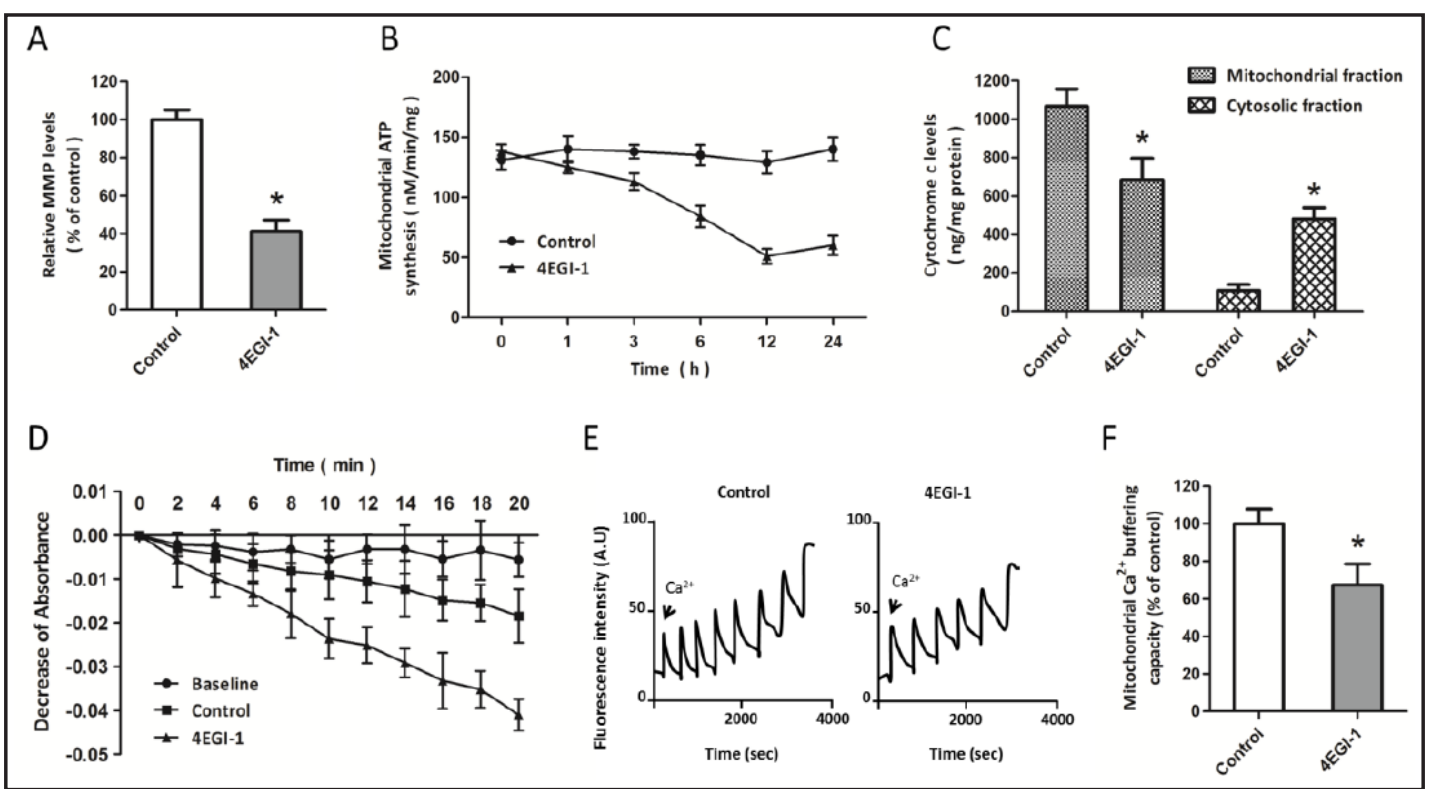

Fig. 4. 4EGI-1 treatment leads to mitochondrial dysfunction in U87 cells. U87 cells were treated with $50 \mu \mathrm{M}$ 4EGI-1, and mitochondria in each group were isolated and purified. The MMP levels (A), mitochondrial ATP synthesis (B) and cytochrome c release (C) were measured. Mitochondrial swelling was examined by monitoring the absorbance at $540 \mathrm{~nm}$ induced by $200 \mu \mathrm{M} \mathrm{Ca}^{2+}(\mathrm{D})$, and the baseline absorbance was measured without $\mathrm{Ca}^{2+}$. Relative $\mathrm{Ca}^{2+}$ uptake capacity of isolated mitochondria were determined (E) and calculated (F). Data are shown as mean \pm SEM of five experiments. ${ }^{*} p<0.05$ vs. Control.

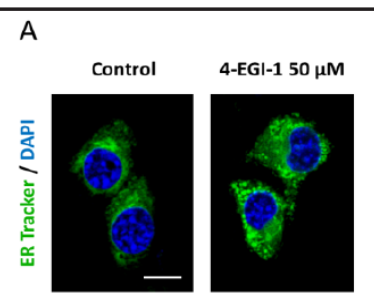

D

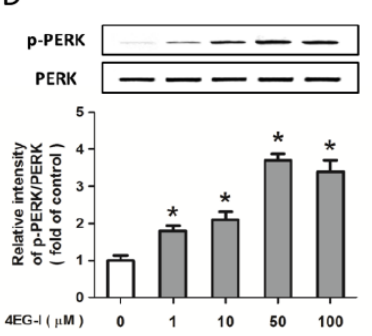

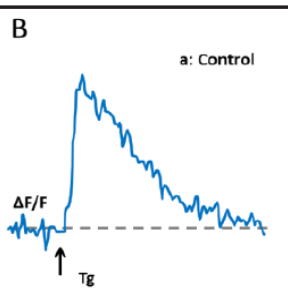

E

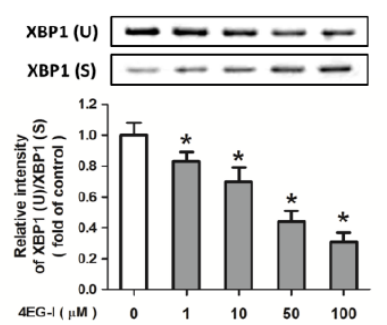

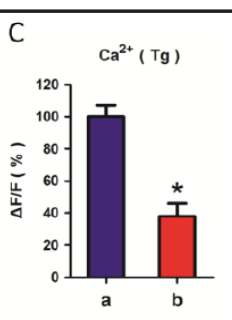

$\mathrm{F}$

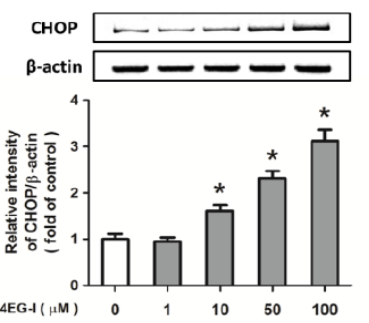

Fig. 5. 4EGI-1 induces ER stress in U87 cells. U87 cells were treated with $50 \mu \mathrm{M} 4 \mathrm{EGI}-1$, and the morphological changes of ER were detected by ER tracker $(\mathrm{A})$. Relative changes in $\mathrm{Ca}^{2+}$ responses $(\Delta \mathrm{F} / \mathrm{F})$ to the application of thapsigargin (Tg) were detected (B and C). U87 cells were treated with 4EGI-1 at different concentrations for $6 \mathrm{~h}$, and the expression of p-PERK, PERK (D), XBP1 (U), XBP1(S) (E) and CHOP (F) were detected by western blot analysis. Scale bars: $20 \mu \mathrm{m}$. Data are shown as mean \pm SEM of five experiments. ${ }^{*} p<0.05$ vs. Control.

4EGI-1 treatment leads to mitochondrial dysfunction in U87 cells

The intrinsic apoptotic pathway is commonly related to mitochondrial dysfunction, and thus we further investigated the effects of 4EGI-1 on mitochondrial function in U87 cells. An 


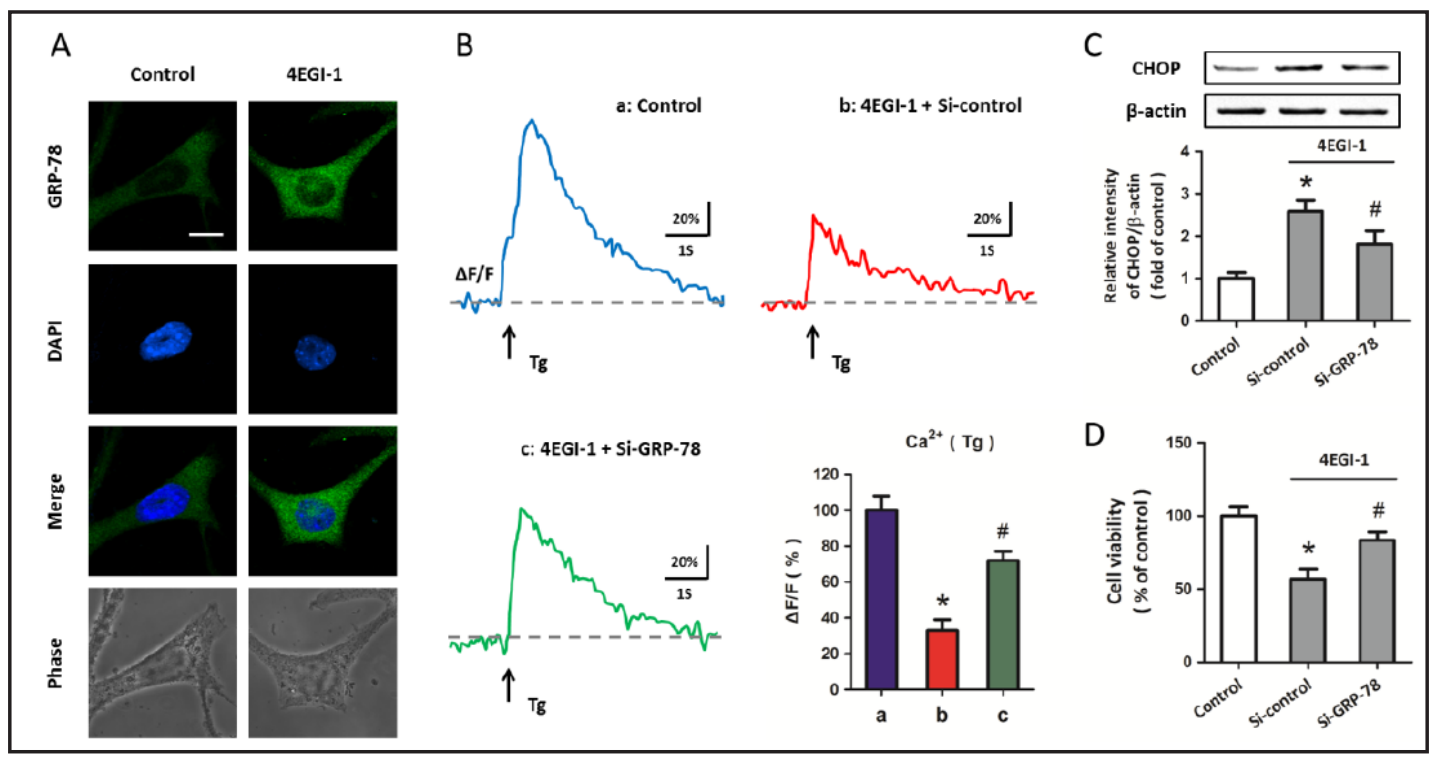

Fig. 6. GRP-78 activation contributes to 4EGI-1-induced ER stress in U87 cells. U87 cells were treated with $50 \mu \mathrm{M} 4 \mathrm{EGI}-1$, and the expression of GRP-78 was detected by fluorescence staining (A). U87 cells were transfected with GRP-78 specific siRNA (Si-GRP-78) or control siRNA (Si-control) for $48 \mathrm{~h}$ before $4 \mathrm{EGI-1}$ exposure, and relative changes in $\mathrm{Ca}^{2+}$ responses $(\Delta \mathrm{F} / \mathrm{F})$ to the application of thapsigargin $(\mathrm{Tg})$ were detected (B). The expression of CHOP was detected by western blot analysis (C), and cell viability was measured (D). Scale bars: $20 \mu \mathrm{m}$. Data are shown as mean \pm SEM of five experiments. ${ }^{*} p<0.05$ vs. Control. ${ }^{*} p<0.05$ vs. Si-control.

obvious collapse of MMP was found after 4EGI-1 exposure (Fig. 4A), and 4EGI-1 also inhibited mitochondrial ATP synthesis in a time-dependent manner (Fig. 4B). We found that 4EGI-1 induces cytochrome c release from mitochondria, as evidenced by increased cytochrome $\mathrm{c}$ in cytosolic fraction and a decrease of mitochondrial cytochrome c content (Fig. 4C). Moreover, we also tested the effect of 4EGI-1 on mitochondria swelling, which was induced by adding $200 \mu \mathrm{M} \mathrm{Ca}^{2+}$ into isolated mitochondria (Fig. 4D). A significant enhancement of mitochondria swelling was detected in 4EGI-1 treated cells as compared to control cells. In addition, we also examined the calcium buffering capacity in isolated mitochondria following 4EGI-1 treatment (Fig. 4E), and 4EGI-1 exposure resulted in a $\sim 40 \%$ reduction in $\mathrm{Ca}^{2+}$ buffering capacity in isolated mitochondria (Fig. 4F).

\section{EGI-1 induces ER stress in U87 cells}

To explore the potential involvement of ER stress in 4EGI-1 induced anti-cancer effect, we first detected the morphological changes of ER using ER tracker staining. As shown in Fig. 5A, 4EGI-1 treatment resulted in an increase in ER dilation and some vacuoles formed from the destruction of ER structural integrity. We then examined the $\mathrm{ER} \mathrm{Ca}^{2+}$ metabolism by measuring thapsigargin ( $\mathrm{Tg}$ ) induced changes in $\mathrm{Ca}^{2+}$ responses (Fig. 5B). The results showed that application of $\mathrm{Tg}$ produced a local $\mathrm{Ca}^{2+}$ transient in control cells but a smaller $\mathrm{Ca}^{2+}$ transient in 4EGI-1 treated cells, indicating more $\mathrm{Ca}^{2+}$ released from ER after 4EGI-1 exposure (Fig. 5C). To further confirm the involvement of ER stress in our in vitro conditions, we also detected the expression of ER stress related proteins such as PERK, XBP1 and CHOP by western blot. As expected, increased phosphorylation of PERK (Fig. 5D), induction of XBP1 splicing (Fig. 5E), and up-regulated CHOP expression (Fig. 5F) were all observed in U87 cells after 4EGI-1 treatment, and these changes were all in dose-dependent manner.

GRP-78 activation contributes to 4EGI-1-induced ER stress in U87 cells

To investigate the molecular mechanisms underlying 4EGI-1 induced ER stress, the expression of ER chaperone GRP-78 was detected by fluorescence staining. As shown in 


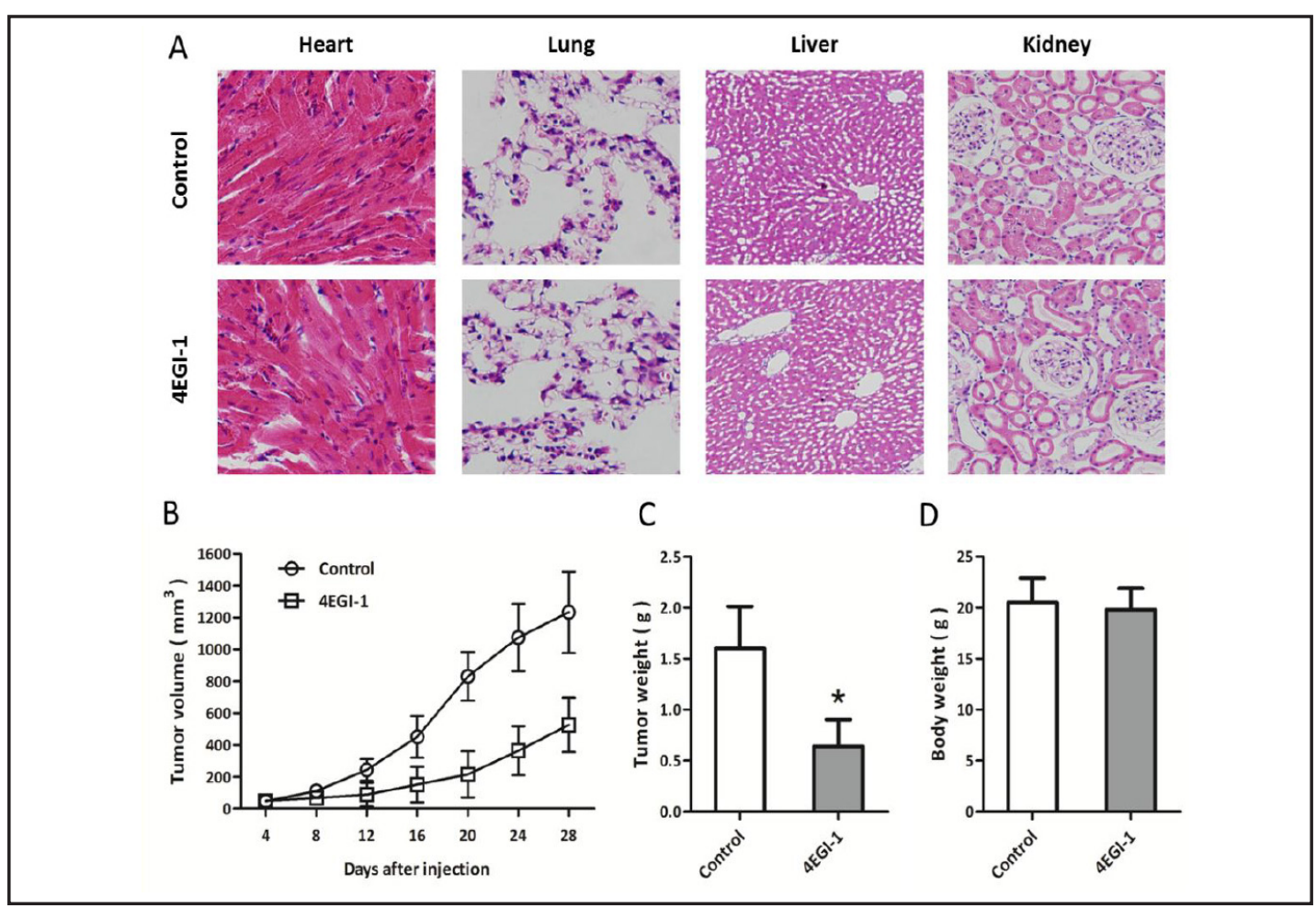

Fig. 7. Anti-tumor effect of 4EGI-1 in U87 xenograft glioma model. The mice were intraperitonealy treated with $4 \mathrm{EGI}-1$ ( $75 \mathrm{mg} / \mathrm{kg}$ ) for every day for 30 days. After the experiment, animals were sacrificed and the organs were fixed in formalin overnight and processed for paraffin embedding. The paraffin-embedded blocks were sectioned and stained by hematoxylin and eosin (A). The athymic nude mice were treated with 4EGI-1 $(75 \mathrm{mg} / \mathrm{kg})$ by intraperitoneal administration every day following U87 cell injection, and the tumor volume was monitored from 4 to 28 days later (B). The tumor weight (C) and body weight (D) were measured at 28 days later. Data are are shown as mean \pm SEM of five experiments. ${ }^{*} p<0.05$ vs. Control.

Fig. 6A, the fluorescence intensity of GRP-78 in cytoplasm was significantly increased by 4EGI-1 treatment as compared to control cells. To determine the important role of GRP-78 induction in 4EGI-1 induced anti-cancer effect, specific targeted siRNA (Si-GRP-78) was used to knockdown its expression in U87 cells. The results of $\mathrm{Ca}^{2+}$ imaging showed that $\mathrm{Tg}$ stimulation produced a larger $\mathrm{Ca}^{2+}$ transients in Si-GRP-78 transfected cells as compared with Si-control transfected group (Fig. 6B), indicating that the 4EGI-1 induced ER $\mathrm{Ca}^{2+}$ release was partially prevented by GRP-78 knockdown. In addition, down-regulation of GRP-78 expression also decreased the induction of CHOP protein after 4EGI-1 treatment (Fig. 6C). Finally, we examined the cell viability. As shown in Fig. 6D, the decrease in cell viability induced by 4EGI-1 was partially reversed by GRP-78 knockdown. All these data strongly suggest that the anti-cancer effect of 4EGI-1 was at least partly mediated by GRP78-dependent ER stress induction.

\section{Anti-tumor effect of 4EGI-1 in U87 xenograft glioma model}

To determine the tumor growth inhibition effects of 4EGI-1 in vivo, we first detected its cytotoxic effects on normal tissues. The mice were intraperitonealy treated with 4EGI$1(75 \mathrm{mg} / \mathrm{kg})$ every day for 30 days, and H\&E staining of the organs collected from our experiments suggested no major organ related toxicities (Fig. 7A). We used an U87 xenograft model in which tumor-bearing mice were treated with $75 \mathrm{mg} / \mathrm{kg} 4 \mathrm{EGI}-1$ by intraperitoneal administration every day after U87 cell injection, and the tumor volume was monitored from 4 to 28 days later. As shown in Fig. 7B, statistical differences in tumor volume were observed between 4EGI-1 group and control group from 12 to $28 \mathrm{~d}$. The tumor weight of 4EGI-1 treated 


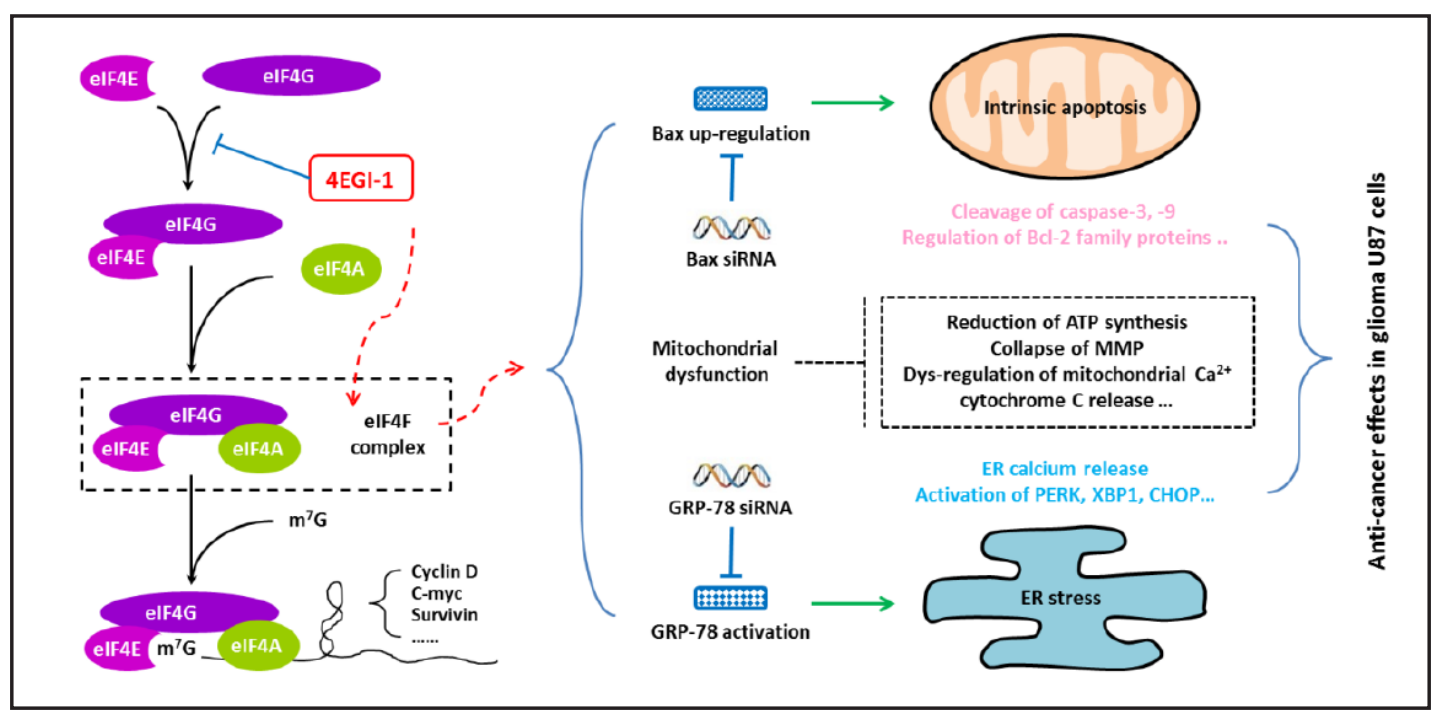

Fig. 8. A proposed diagram tying together the various observations involved in 4EGI-1 induced anticancer effects in glioma U87 cells.

mice was significantly less than that of the negative control (Fig. 7C). By contrast, there was no significant loss in body weight in these experimental animals (Fig. 7D).

\section{Discussion}

Overexpression and excessive activation of translation initiation factors lead to malignant transformation and maintenance of transformed phenotypes both in vitro and in vivo $[22,23]$. Among multiple translation initiation factors, elevated eIF4E function triggers enhanced assembly of the eIF4F complex, which in turn drives cap-dependent translation. 4EGI-1 is a hit compound discovered in a screening campaign of small molecule libraries as an inhibitor of translation initiation factors eIF4E and eIF4G protein-protein interaction [24]. It is an ideal alternative to inhibit eIF4E function and eIF4F complex formation for using antisense oligonucleotide, and has been demonstrated to be an efficacious anticancer agent in animal models of multiple human cancers [25]. In the present study, by pull-down assays using $7 \mathrm{~m}$-GTP sepharose beads that mimic the cap structure of mRNA, we found that incubation with 4EGI-1 strongly decreased the amount of eIF4G bound to eIF4E in glioma U87 cells, which was consistent with previous studies in several other human cancer cell lines $[17,26]$. In addition, we also observed inhibitory effects of 4EGI-1 on the expression of survivin, c-myc and cyclin D proteins, which are all well known to be regulated through cap-dependent translation initiation mechanisms [11, 27, 28]. Interestingly, in our in vitro conditions, neither the expression nor the phosphorylation levels of eIF4E and 4E-BP1 was altered by $4 \mathrm{EGI}-1$ treatment. These data indicated that 4EGI-1 inhibits the eIF4EeIF4G interaction independently of the 4E-BPs and might indeed result in a significant enhancement of 4E-BP1 binding to eIF4E [15]. These characteristics of 4EGI-1 provide a novel chemical genetic tool with which to investigate translational control of cancer related gene expression, and also can be useful for anti-cancer drug research for glioma patients.

Owing to their essential roles in energy metabolism and regulation of apoptosis related signaling cascades, mitochondria are considered as an attractive target for cancer therapy. Several agents that impact mitochondrial function have been identified to exert anti-cancer activity in both in vitro and in vivo models, and one common feature of these compounds is their preferential killing of cancer cells with low cytotoxicity to normal cells [29]. In the present study, obvious collapse of MMP and a time-dependent decrease in mitochondrial ATP synthesis were found in U87 cells after 4EGI-1 incubation, indicating the involvement of 


\section{Cellular Physiology Cell Physiol Biochem 2016;40:1013-1028 \\ and Biochemistry Published online: December 12, $2016 \quad \begin{aligned} & \text { DOI: } 2016 \text { The Author(s). Published by S. Karger AG, Basel } \\ & \text { www.karger.com/cpb }\end{aligned}$ \\ Wu et al.: Anti-Cancer Effect of 4EGI-1 in Glioma Cells}

mitochondrial dysfunction in 4EGI-1 induced cell death in glioma cells. It has been recognized that increased mitochondrial stress in cancer cells is associated with the aggressiveness of tumors and poor prognosis. When the mitochondrial stress reaches a certain threshold level that exceeds the cellular capacity, it may exert a cytotoxic effect and suppress cancer progression, which is characterized by swelling of mitochondrial membranes and opening of the permeability pore to release the apoptosis factors such as cytochrome c [30]. These characteristic changes were all observed in isolated mitochondria after 4EGI-1 treatment in our experiments. One of the key events that kills cells through mitochondrial injury is an abnormal increase in mitochondrial $\mathrm{Ca}^{2+}$, induced by receptor-mediated $\mathrm{Ca}^{2+}$ influx or $\mathrm{Ca}^{2+}$ release from intracellular stores [31]. Mitochondria serve as an intracellular calcium buffer shaping $\mathrm{Ca}^{2+}$ signaling, and mitochondrial $\mathrm{Ca}^{2+}$ loading has been shown to play a crucial role in apoptotic cell death [32]. Our results showing that 4EGI-1 decreased mitochondrial $\mathrm{Ca}^{2+}$ buffering capacity in U87 cells further confirmed the hypothesis that 4EGI-1-induced anticancer effects are partially mediated by mitochondrial dysfunction related apoptosis.

Abnormal decreases in apoptosis have been considered as a key mechanism responsible for the accumulation of cancer cells, including human gliomas [33]. In line with the results of mitochondrial dysfunction in U87 cells, we also observed activation of intrinsic apoptotic pathway, as evidenced by cleavage of caspase- 9 and caspase-3 after 4EGI-1 incubation, indicating that targeting abnormal decrease in apoptosis might be also a mechanism of 4EGI1 treatment. Although the detailed molecular mechanisms that govern the mitochondrial apoptotic cascades, especially in cancer conditions, still remain to be elucidated, the Bcl2 family proteins are shown to play major roles [34]. In the present study, we identified a novel mechanism that 4EGI-1 induces intrinsic apoptotic cell death through a Baxdependent but Bak-independent manner. Bax and Bak are two pro-apoptotic Bcl-2 family members that activated by BH3-only proteins and inhibited by pro-survival Bcl-2 proteins via direct interactions [35]. Following a variety of stress signals, they convert into poreforming proteins by changing conformation and assembling into oligomeric complexes in the mitochondrial outer membrane (MOM) [36]. In normal conditions, Bak is inserted in the MOM, whereas Bax is predominantly cytosolic with a minor population loosely attached to the MOM [37, 38]. These differences in subcellular distribution of Bax and Bak might explain their different roles observed in our experiments. In addition, the Bak nine $\alpha$-helices $(\alpha 9)$ are more hydrophobic than that of Bax, and appear to prefer the hydrophobic membrane environment rather than the amphipathic environment of the Bak groove [35, 39]. Consistent with this, when the Bak tail was mutated to make it more hydrophilic (Bax-like), the mutant Bak protein became more cytosolic with binding of the tail to the groove $[35,40]$. In future experiments, the Bax-dependent but Bak-independent mechanisms observed in this study should be further determined in other cancer cells or in in vivo conditions.

Previous anti-cancer research using pro-apoptotic compounds was commonly focused on cell cycle arrest, mitochondrial pathway or oxidative stress [41]. In the past few decades, ER stress, a more recently discovered biochemical cascade, is considered as a significant regulator of apoptosis and has been considered as the third apoptosis mechanism besides the classic extrinsic and intrinsic pathways [42]. Recently, a number of anti-cancer therapies have been shown to be associated with the induction of ER stress in tumor cells [43]. The ER stress is a cellular response to a variety of endogenous and exogenous insults that trigger the

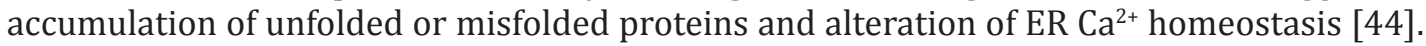
It can improve cell survival through the unfolded protein response (UPR) or kill the stressed cells via apoptotic cell death $[18,45]$. The UPR and its signaling "arms", such as pancreatic ER kinase (PKR)-like ER kinase (PERK), are shown to be differently deregulated in cancer patients, and might contribute to anti-apoptotic activity and drug resistance of cancer cells [46]. In our present study, 4EGI-1 treatment was shown to increase PERK phosphorylation and the XBP1S mRNA expression in a dose-dependent manner, which has a diverse range of target genes that are associated with apoptotic pathway [47]. This effect was accompanied by the morphological changes in ER lumen and induction of CHOP protein, a transcription factor downstream of the PERK-ATF4 axis that induces apoptosis via suppressing the transcription 
of anti-apoptotic Bcl-2 and inducing ROS production [48]. In addition, significant increase in $\mathrm{ER} \mathrm{Ca}^{2+}$ release, another characteristic cellular event of ER stress, was also observed after 4EGI-1 exposure in U87 cells. Considering the fact that the mitochondrial pathway is thought to be fundamental for the determination of cell fate under ER stress conditions $[49,50]$, all these data observed here strongly suggest that 4EGI-1 induced anti-cancer effect might be associated with activation of ER stress related apoptotic cascades.

The molecular mechanisms underlying ER stress related apoptosis in cancer cells are not straightforward and may involve signaling pathways with dualistic function in cell survival and death $[42,51]$. Our present data using specific siRNA, for the first time, support a molecular mechanism whereby 4EGI-1 treatment increases the expression of GRP-78, which is required for the induction of CHOP under ER stress conditions. GRP-78, also known as BiP, belongs to the heat shock protein (HSP) 70 family. It is referred to as ER molecular chaperone due to its ubiquitous expression in ER and its ability to assist in protein folding and assembly [52]. Unlike its homologues, GRP-78 exerts different functions with multifaceted subcellular position: serves as the switch of UPR within ER lumen; interacts with apoptotic executors with binding to mitochondria; or mediates transducing signaling through extracellular ligands residing cell surface [53]. In our in vitro model, increased expression of GRP-78 was found to be related to induction of ER stress and apoptotic cell death, which was consistent with previous studies using several other anti-cancer agents $[54,55]$. The inhibition of capdependent translation initiation induced by 4EGI-1 might influence the expression, activation or folding of several downstream proteins, such as survivin, c-myc and cyclin D proteins, which are demonstrated here and by previous studies [17]. These effects might also lead to an imbalance between protein folding load and capacity, which in turn activates GRP-78 and UPR to re-establish ER homeostasis. In addition, we also detected decreased $\mathrm{Ca}^{2+}$ release and CHOP activation after GRP-78 knockdown, indicating the involvement of GRP-78 in 4EGI-1 induced apoptosis. In contrast, a previous study showed a close association of elevated GRP78 expression with increased astrocytoma malignancy via activating Akt and ERK pathways [56]. Those pro-proliferative effects of GRP-78 in glioma cells might reflect its function with cell surface localization. In the present study, our fluorescence staining results showed that GRP-78 localized mainly within cytoplasm, where it could interact with ER or mitochondria to mediate pro-apoptotic signaling. As one limitation of this study, some further experiments should be performed to determine whether the GRP-78 related mechanism observed here was due to its localization in ER or mitochondria.

\section{Conclusions}

In conclusion, our present study showed that inhibition of the translation initiation complex eIF4F via a small molecule 4EGI-1 exerts anti-cancer effect in human glioma U87 cells both in vivo and in vitro. These effects are mediated by Bax-dependent activation of the mitochondrial apoptotic pathway and GRP-78-dependent induction of the ER stress (Fig. 8). Taken together with the notion that malignant cells are preferentially susceptible to the inhibition of cap-dependent translation, our data suggest that inhibiting eIF4F complex formation could become a very attractive and potentially effective therapy in human glioma.

\section{Acknowledgements}

This work was financially supported by the National Natural Science Foundation of China (No. 30901539).

\section{Disclosure Statement}

The authors report no conflicts of interest. 


\section{Cellular Physiology Cell Physiol Biochem 2016;40:1013-1028

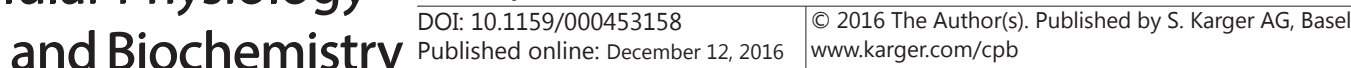 \\ Wu et al:: Anti-Cancer Effect of 4EGI-1 in Glioma Cells}

\section{References}

1 Dolecek TA, Propp JM, Stroup NE, Kruchko C: CBTRUS statistical report: primary brain and central nervous system tumors diagnosed in the United States in 2005-2009. Neuro Oncol 2012;14 Suppl 5:v1-49.

2 Louis DN, Holland EC, Cairncross JG: Glioma classification: a molecular reappraisal. Am J Pathol 2001;159:779-786.

3 Stupp R, Mason WP, van den Bent MJ, Weller M, Fisher B, Taphoorn MJ, Belanger K, Brandes AA, Marosi C, Bogdahn U, Curschmann J, Janzer RC, Ludwin SK, Gorlia T, Allgeier A, Lacombe D, Cairncross JG, Eisenhauer E, Mirimanoff RO: Radiotherapy plus concomitant and adjuvant temozolomide for glioblastoma. N Engl J Med 2005;352:987-996.

4 Tran B, Rosenthal MA: Survival comparison between glioblastoma multiforme and other incurable cancers. J Clin Neurosci 2010;17:417-421.

5 Liu Y, Liu R, Fu P, Du F, Hong Y, Yao M, Zhang X, Zheng S: N1-Guanyl-1,7-Diaminoheptane Sensitizes Estrogen Receptor Negative Breast Cancer Cells to Doxorubicin by Preventing Epithelial-Mesenchymal Transition through Inhibition of Eukaryotic Translation Initiation Factor 5A2 Activation. Cell Physiol Biochem 2015;36:2494-2503.

6 Gao Q Yao X, Zheng J: MiR-323 Inhibits Prostate Cancer Vascularization Through Adiponectin Receptor. Cell Physiol Biochem 2015;36:1491-1498.

7 Siebzehnrubl FA, Reynolds BA, Vescovi A, Steindler DA, Deleyrolle LP: The origins of glioma: E Pluribus Unum? Glia 2011;59:1135-1147.

8 Kapp LD, Lorsch JR: The molecular mechanics of eukaryotic translation. Annu Rev Biochem 2004;73:657704.

9 Pelletier J, Graff J, Ruggero D, Sonenberg N: Targeting the eIF4F translation initiation complex: a critical nexus for cancer development. Cancer Res 2015;75:250-263.

10 Li J, Yu T, Cao J, Liu L, Liu Y, Kong HW, Zhu MX, Lin HC, Chu DD, Yao M, Yan MX: MicroRNA-148a Suppresses Invasion and Metastasis of Human Non-Small-Cell Lung Cancer. Cell Physiol Biochem 2015;37:1847-1856.

11 Konicek BW, Dumstorf CA, Graff JR: Targeting the eIF4F translation initiation complex for cancer therapy. Cell Cycle 2008; 7:2466-2471.

12 Lazaris-Karatzas A, Montine KS, Sonenberg N: Malignant transformation by a eukaryotic initiation factor subunit that binds to mRNA 5' cap. Nature 1990;345:544-547.

13 Ruggero D, Montanaro L, Ma L, Xu W, Londei P, Cordon-Cardo C, Pandolfi PP: The translation factor eIF-4E promotes tumor formation and cooperates with c-Myc in lymphomagenesis. Nat Med 2004;10:484-486.

14 Chen L, Aktas BH, Wang Y, He X, Sahoo R, Zhang N, Denoyelle S, Kabha E, Yang H, Freedman RY, Supko JG, Chorev M, Wagner G, Halperin JA: Tumor suppression by small molecule inhibitors of translation initiation. Oncotarget 2012;3:869-881.

15 Moerke NJ, Aktas H, Chen H, Cantel S, Reibarkh MY, Fahmy A, Gross JD, Degterev A, Yuan J, Chorev M, Halperin JA, Wagner G: Small-molecule inhibition of the interaction between the translation initiation factors eIF4E and eIF4G. Cell 2007;128:257-267.

16 Fan S, Li Y, Yue P, Khuri FR, Sun SY: The eIF4E/eIF4G interaction inhibitor 4EGI-1 augments TRAILmediated apoptosis through c-FLIP Down-regulation and DR5 induction independent of inhibition of capdependent protein translation. Neoplasia 2010;12:346-356.

17 Descamps G, Gomez-Bougie P, Tamburini J, Green A, Bouscary D, Maiga S, Moreau P, Le Gouill S, PellatDeceunynck C, Amiot M: The cap-translation inhibitor 4EGI-1 induces apoptosis in multiple myeloma through Noxa induction. Br J Cancer 2012;106:1660-1667.

18 Chen T, Fei F, Jiang XF, Zhang L, Qu Y, Huo K, Fei Z: Down-regulation of Homer1b/c attenuates glutamatemediated excitotoxicity through endoplasmic reticulum and mitochondria pathways in rat cortical neurons. Free Radic Biol Med 2012;52:208-217.

19 Parone PA, Da Cruz S, Han JS, McAlonis-Downes M, Vetto AP, Lee SK, Tseng E, Cleveland DW: Enhancing mitochondrial calcium buffering capacity reduces aggregation of misfolded SOD1 and motor neuron cell death without extending survival in mouse models of inherited amyotrophic lateral sclerosis. J Neurosci 2013;33:4657-4671.

20 Yu Z, Liu N, Li Y, Xu J, Wang X: Neuroglobin overexpression inhibits oxygen-glucose deprivation-induced mitochondrial permeability transition pore opening in primary cultured mouse cortical neurons. Neurobiol Dis 2013;56:95-103. 


\section{Cellular Physiology Cell Physiol Biochem 2016;40:1013-1028

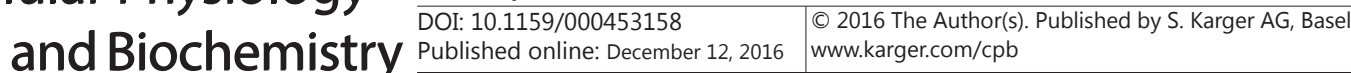 \\ Wu et al.: Anti-Cancer Effect of 4EGI-1 in Glioma Cells}

21 Hartmann J, Karl RM, Alexander RP, Adelsberger H, Brill MS, Ruhlmann C, Ansel A, Sakimura K, Baba Y, Kurosaki T, Misgeld T, Konnerth A: STIM1 controls neuronal Ca(2)(+) signaling, mGluR1-dependent synaptic transmission, and cerebellar motor behavior. Neuron 2014;82:635-644.

22 Clemens MJ: Targets and mechanisms for the regulation of translation in malignant transformation. Oncogene 2004;23:3180-3188.

23 Mamane Y, Petroulakis E, Rong L, Yoshida K, Ler LW, Sonenberg N: eIF4E--from translation to transformation. Oncogene 2004;23:3172-3179.

24 Takrouri K, Chen T, Papadopoulos E, Sahoo R, Kabha E, Chen H, Cantel S, Wagner G, Halperin JA, Aktas BH, Chorev M: Structure-activity relationship study of 4EGI-1, small molecule eIF4E/eIF4G protein-protein interaction inhibitors. Eur J Med Chem 2014;77:361-377.

25 Graff JR, Konicek BW, Carter JH, Marcusson EG: Targeting the eukaryotic translation initiation factor 4E for cancer therapy. Cancer Res 2008;68:631-634.

26 Willimott S, Beck D, Ahearne MJ, Adams VC, Wagner SD: Cap-translation inhibitor, 4EGI-1, restores sensitivity to ABT-737 apoptosis through cap-dependent and -independent mechanisms in chronic lymphocytic leukemia. Clin Cancer Res 2013;19:3212-3223.

27 De Benedetti A, Graff JR: eIF-4E expression and its role in malignancies and metastases. Oncogene 2004;23:3189-3199.

28 Jia Y, Polunovsky V, Bitterman PB, Wagner CR: Cap-dependent translation initiation factor eIF4E: an emerging anticancer drug target. Med Res Rev 2012;32:786-814.

29 Chen G, Wang F, Trachootham D, Huang P: Preferential killing of cancer cells with mitochondrial dysfunction by natural compounds. Mitochondrion 2010;10:614-625.

30 Burz C, Berindan-Neagoe I, Balacescu 0, Irimie A: Apoptosis in cancer: key molecular signaling pathways and therapy targets. Acta Oncol 2009;48:811-821.

31 Williams GS, Boyman L, Chikando AC, Khairallah RJ, Lederer WJ: Mitochondrial calcium uptake. Proc Natl Acad Sci U S A 2013;110:10479-10486.

32 Szalai G, Krishnamurthy R, Hajnoczky G: Apoptosis driven by IP(3)-linked mitochondrial calcium signals. EMBO J 1999;18:6349-6361.

33 Bogler 0, Mikkelsen T: Angiogenesis and apoptosis in glioma: two arenas for promising new therapies. J Cell Biochem 2005;96:16-24.

34 Youle RJ, Strasser A: The BCL-2 protein family: opposing activities that mediate cell death. Nat Rev Mol Cell Biol 2008;9:47-59.

35 Westphal D, Kluck RM, Dewson G: Building blocks of the apoptotic pore: how Bax and Bak are activated and oligomerize during apoptosis. Cell Death Differ 2014;21:196-205.

36 Westphal D, Dewson G, Czabotar PE, Kluck RM: Molecular biology of Bax and Bak activation and action. Biochim Biophys Acta 2011;1813:521-531.

37 Griffiths GJ, Dubrez L, Morgan CP, Jones NA, Whitehouse J, Corfe BM, Dive C, Hickman JA: Cell damageinduced conformational changes of the pro-apoptotic protein Bak in vivo precede the onset of apoptosis. J Cell Biol 1999;144:903-914.

38 Wolter KG, Hsu YT, Smith CL, Nechushtan A, Xi XG, Youle RJ: Movement of Bax from the cytosol to mitochondria during apoptosis. J Cell Biol 1997;139:1281-1292.

39 Ferrer PE, Frederick P, Gulbis JM, Dewson G, Kluck RM: Translocation of a Bak C-terminus mutant from cytosol to mitochondria to mediate cytochrome $\mathrm{C}$ release: implications for Bak and Bax apoptotic function. PLoS One 2012;7:e31510.

40 Leshchiner ES, Braun CR, Bird GH, Walensky LD: Direct activation of full-length proapoptotic BAK. Proc Natl Acad Sci U S A 2013;110:E986-995.

41 Ziedan NI, Kadri H, Westwell AD: The development of pro-apoptotic cancer therapeutics. Mini Rev Med Chem 2008;8:711-718.

42 Verfaillie T, Garg AD, Agostinis P: Targeting ER stress induced apoptosis and inflammation in cancer. Cancer Lett 2013;332:249-264.

43 Garg AD, Agostinis P: ER stress, autophagy and immunogenic cell death in photodynamic therapy-induced anti-cancer immune responses. Photochem Photobiol Sci 2014;13:474-487.

44 Kania E, Pajak B, Orzechowski A: Calcium Homeostasis and ER Stress in Control of Autophagy in Cancer Cells. Biomed Res Int 2015;2015:352794. 


\section{Cellular Physiology Cell Physiol Biochem 2016;40:1013-1028 \begin{tabular}{ll|l} 
DOI: 10.1159/000453158 & O 2016 The Author(s). Published by S. Karger AG, Basel \\
and Biochemistry & Published online: December 12, 2016 & muwwkarger.com/cpb
\end{tabular} \\ Wu et al.: Anti-Cancer Effect of 4EGI-1 in Glioma Cells}

45 Mori K: Tripartite management of unfolded proteins in the endoplasmic reticulum. Cell 2000;101:451-454.

46 Mahoney E, Byrd JC, Johnson AJ: Autophagy and ER stress play an essential role in the mechanism of action and drug resistance of the cyclin-dependent kinase inhibitor flavopiridol. Autophagy 2013;9:434-435.

47 Wang WA, Groenendyk J, Michalak M: Endoplasmic reticulum stress associated responses in cancer. Biochim Biophys Acta 2014;1843:2143-2149.

48 McCullough KD, Martindale JL, Klotz LO, Aw TY, Holbrook NJ: Gadd153 sensitizes cells to endoplasmic reticulum stress by down-regulating $\mathrm{Bcl} 2$ and perturbing the cellular redox state. Mol Cell Biol 2001;21:1249-1259.

49 Csordas G, Renken C, Varnai P, Walter L, Weaver D, Buttle KF, Balla T, Mannella CA, Hajnoczky G: Structural and functional features and significance of the physical linkage between ER and mitochondria. J Cell Biol 2006;174:915-921.

50 Giorgi C, De Stefani D, Bononi A, Rizzuto R, Pinton P: Structural and functional link between the mitochondrial network and the endoplasmic reticulum. Int J Biochem Cell Biol 2009;41:1817-1827.

51 Lee AS, Hendershot LM: ER stress and cancer. Cancer Biol Ther 2006;5:721-722.

52 Gething MJ, Sambrook J: Protein folding in the cell. Nature 1992;355:33-45.

53 Zhang LH, Zhang X: Roles of GRP78 in physiology and cancer. J Cell Biochem 2010;110:1299-1305.

54 Zhao Y, Zhu C, Li X, Zhang Z, Yuan Y, Ni Y, Liu T, Deng S, Zhao J, Wang Y: Asterosaponin 1 induces endoplasmic reticulum stress-associated apoptosis in A549 human lung cancer cells. Oncol Rep 2011;26:919-924.

55 Lu JJ, Chen SM, Zhang XW, Ding J, Meng LH: The anti-cancer activity of dihydroartemisinin is associated with induction of iron-dependent endoplasmic reticulum stress in colorectal carcinoma HCT116 cells. Invest New Drugs 2011;29:1276-1283.

56 Zhang LH, Yang XL, Zhang X, Cheng JX, Zhang W: Association of elevated GRP78 expression with increased astrocytoma malignancy via Akt and ERK pathways. Brain Res 2011;1371:23-31. 